\title{
Exploring Dynamics Affecting Learners' English Listening Comprehension in the EFL Classrooms: Secondary Schools in Focus, North Western Ethiopia
}

\author{
Melaku Bayu Workie \\ Lecturer, Department of English Language and Literature, Faculty of Social Sciences and Humanities, Debre \\ Tabor University, Debre Tabor, Ethiopia
}

\begin{abstract}
The main objective of this study was to explore factors affecting students' English listening comprehension in the EFL classrooms in the case of grade nine students at Dagmawi Tewodros secondary and preparatory school in Debre Tabor. The study used a descriptive survey design that involves quantitative and qualitative methods. Questionnaire and interview were used to gather the necessary data for the study. Four grade nine English teachers and 118 grade nine students of the school were used as the subject of the study; and they were randomly chosen. Descriptive statistics such as frequencies and percentages were employed in analyzing the quantitative data. The qualitative data were analyzed and reported thematically. The overall findings of the study showed that the authenticity of the listening text, lack of consecutive practice, delinquent language pattern/grammar, inability to grasp speaker's pronunciation, dearth of vocabulary, privation of concentration and lack of interest are some of the factors that affect students' English listening comprehension. Based on the findings, it is recommended that creating meaningful English listening teaching opportunities through various listening teaching modus operandi are supposed to be practiced widely. Auxiliary studies were acclaimed.
\end{abstract}

Keywords: Listening comprehension, Explore, EFL, TEFL, Learners, Dynamics

DOI: $10.7176 /$ JLLL/61-03

Publication date:October $31^{\text {st }} 2019$

\section{Introduction}

Teaching English as a foreign language (TEFL) is a challenging task in developing countries in general and in our country in particular. English has been included in the curriculum of Ethiopian schools and universities, and considerable attention has been paid to this language in our society, for access to and use of the latest technological and scientific resources mainly written in English calls for an efficient amount of English language proficiency (Badakhshan, S., 2008).

People communicate using different language skills. In language teaching, the four main skills are classified into two types: receptive (reading and listening) where language is acquired and meaning is extracted, and productive (writing and speaking) skills, where language is produced. Furthermore, when learning a foreign language people usually want to be engaged in real communication with those who speak the target language; they have the need to understand what others say to be understood.

According to Steinberg (2007), listening skill is defined as the ability of one individual perceiving another via sense (specifically aural) organs, assigning a meaning to the message and comprehending it. However, listening is more complex than merely hearing. Nunan (1998) believed that listening is the basic skill in language learning. Without listening skill, learners will never learn to communicate effectively.

It was known that listening skill had been the ignored skill in the Ethiopian school curriculum. Tesfaye (2008) \& Hubbard (1983) stated that without listening a student may express him or herself orally, but he or she would never be able to understand what was said to him or her.

Due to this, there has always been compliant about students' poor listening ability. Here this study attempted to explore the factors that affect students' English listening comprehension in the English classroom. Listening skill is one of the basic skills in teaching and learning. It is important way for acquiring knowledge from written and recorded audio materials. Concerning this students should have the ability of good listening skill because it is important to get an idea about their topic and academic area.

According to Lund, R. (1991) there are also challenges in listening skill in all levels of schools and university students such challenges help to take corrective major for better most of the students listening capacity so that tremendous attention should be given for listening skill. Students fail to listen effectively - what is being said in the classroom; they cannot acquire the intended language. A number of language scholars have provided various problems by which active listening can be negatively affected (Lindsay, C. and Knight, P. 2006).

In many Ethiopian schools including higher educational institutions, students fail to understand (listen) what someone else's said. Most teachers had complains about the low achievement of the students in listening comprehension. Little has been done, however, to investigate this problem. 


\section{Research Questions}

The study attempted to answer the following research questions in particular.

* What are the factors that contribute to the problems of learners' English listening comprehension?

$\neq$ Which particular factor poses the most difficulty for the learners?

\section{Objectives of the Study}

\subsection{General objective}

The main objective of this study is to explore factors affecting grade nine students' English listening comprehension at Dagmawi Tewodros Secondary and Preparatory School.

\subsection{Specific Objectives}

The specific objectives of the study are to:

4 identify the factors that contribute to the problems of students' English listening comprehension.

$\downarrow$ find out which particular factor poses more difficulty for the learners.

\section{Materials and Method}

\subsection{Research Design}

In this study descriptive research design, which aim to get data about the status of phenomena, was employed. It is concerned with providing description of phenomena that occur naturally without intervention of an experiment. Qualitative and quantitative approaches were used. Quantitative data were used through questionnaire, and qualitative data were used through interview.

\subsection{Participants of the Study}

The study was conducted in Amara region in South Gondar Zone particularly in Debre Tabor town. The target populations of this study were English teachers, who were teaching grade nine students and grade nine students of Dagmawi Tewodros Secondary and Preparatory School in 2018/2019 academic year. Grade nine students were selected for the study since the researcher had personally witnessed the problem under investigation at this level.

\subsection{Sample Size and Sampling Technique}

In the study, the target population were 1180 grade nine students; 636 were females and 544 were males. And there were 24 sections. Ten sections were randomly selected for the study. 118 students were ( 64 female and 54 male) selected through lottery method for questionnaire. And six students were selected via simple random sampling technique for interview. Grade nine English teachers were the other participants of this study. There were seven English teachers who were teaching grade nine students. Among them, four English teachers were randomly selected for interview.

\subsection{Data Gathering Instruments}

To obtain adequate information for the study, data collection tools were employed, notably, questionnaire (opened and closed-ended questions) and interview (structured and unstructured). The instruments were selected because of their suitability for gathering important data for the study.

\subsection{Data Collection Procedure}

The data collection sessions were arranged according to the times suggested by the school doyens' and the willingness of the participants. First, questionnaire was distributed to 118 students in their formal class time and clear information from respondents were collected. Then, interviews with both teachers and students were conducted.

\subsection{Method of Data Analysis}

The collected data were analyzed, interpreted and discussed accordingly. Quantitative data which were collected from the respondents were analyzed using frequency and percentage. Finally, the qualitative data obtained through interview were analyzed thematically. 


\section{Results and Discussion}

\subsection{Respondents' Responses to Items Related to the Listening Text, Listener, Speaker and Environment} Factors

Table 5.1.1: Frequency and percentage of responses to items related to the listening text.

The listening text itself may be the main source of listening comprehension problems. In particular, unfamiliar words, difficult grammatical structures, and the length of the spoken text may present students with listening problems.

\begin{tabular}{|c|c|c|c|c|c|c|c|c|}
\hline \multirow[t]{2}{*}{ Item } & \multirow{2}{*}{\multicolumn{2}{|c|}{ Statement }} & \multicolumn{5}{|c|}{ Responses } & \multirow[t]{2}{*}{ Total } \\
\hline & & & 5 & 4 & 3 & 2 & 1 & \\
\hline \multirow[t]{2}{*}{1} & \multirow{2}{*}{$\begin{array}{l}\text { Unfamiliar words including jargons and idioms } \\
\text { interfered with my listening comprehension. }\end{array}$} & $\mathbf{F}$ & 26 & 61 & 13 & 12 & 6 & 118 \\
\hline & & $\%$ & 22 & 51.7 & 11.1 & 10.1 & 5.1 & 100 \\
\hline \multirow[t]{2}{*}{2} & \multirow{2}{*}{$\begin{array}{l}\text { Complex grammatical structures interfered with my } \\
\text { listening comprehension. }\end{array}$} & $\mathbf{F}$ & 54 & 23 & 10 & 17 & 14 & 118 \\
\hline & & $\%$ & 45.8 & 19.5 & 8.5 & 14.4 & 11.8 & 100 \\
\hline \multirow[t]{2}{*}{3} & \multirow{2}{*}{$\begin{array}{l}\text { Long spoken text made me tired and interfered with my } \\
\text { listening comprehension. }\end{array}$} & $\mathbf{F}$ & 44 & 24 & 12 & 23 & 15 & 118 \\
\hline & & $\%$ & 37.3 & 20.3 & 10.2 & 19.5 & 12.7 & 100 \\
\hline \multirow[t]{2}{*}{4} & \multirow{2}{*}{$\begin{array}{l}\text { Information that was not crucial to me and that could } \\
\text { not generate sufficient interest to me did not make me to } \\
\text { continue listening. }\end{array}$} & $\mathbf{F}$ & 20 & 40 & 28 & 16 & 14 & 118 \\
\hline & & $\%$ & 17 & 34 & 23.7 & 13.5 & 11.8 & 100 \\
\hline \multirow[t]{2}{*}{5} & \multirow{2}{*}{$\begin{array}{l}\text { The length and complexity of sentences interfered with } \\
\text { my listening comprehension. }\end{array}$} & $\mathbf{F}$ & 40 & 22 & 26 & 14 & 16 & 118 \\
\hline & & $\%$ & 34 & 18.6 & 22 & 11.9 & 13.5 & 100 \\
\hline \multirow[t]{2}{*}{6} & \multirow{2}{*}{$\begin{array}{l}\text { Unfamiliar topic/subject matter interfered with my } \\
\text { listening comprehension. }\end{array}$} & $\mathbf{F}$ & 23 & 54 & 10 & 14 & 17 & 118 \\
\hline & & $\%$ & 19.5 & 45.8 & 8.5 & 11.8 & 14.4 & 100 \\
\hline
\end{tabular}

Key: $\mathbf{5}=$ Always $\mathbf{4}=$ Usually $\mathbf{3}=$ Sometimes $\mathbf{2}=$ Rarely $\quad \mathbf{1}=$ Never $\quad \boldsymbol{F}=$ Frequency $\quad \boldsymbol{\%}=$ Percent

The great majority of the respondents $(84.8 \%)$ responded that unfamiliar words, including jargon and idioms (sometimes, usually, always) interfered with their listening comprehension, and more than half of the students have also responded that this problem often or always interfered with their listening comprehension.

The second question (see item number 2) was asked to know whether complex grammatical structures interfered with the learners' listening comprehension. The great majority of the students $(73.8 \%)$ have responded that difficult grammatical structures (sometimes, often, always) interfered with their listening comprehension.

From the result obtained above, it is possible to generalize that unfamiliar words, complex grammatical structures, and complex sentences interfere with the listening comprehension of the great majority of the students. This confirms Rubin's opinion (1998) which shows that the difficulty in listening comprehension is partly due to the structural component of the text. This might be due to completely relying on the bottom-up processing strategy in which learners make use of the analysis of words and sentence structure to enhance their understanding of the spoken text, and this might be due to the inadequacy of the top-down processing strategy in which learners make use of their previous knowledge, which is not directly encoded in words, that means, without examining words and structures.

Table 5.1.2: Frequency and percentage of responses to items related to listener factors.

Listeners' problems may arise from inability to use appropriate listening strategies, inability to grasp pronunciation, frustration, listen only to voice without seeing the speaker's facial expressions and gesture, and the demand of other skills at the expense of listening.

\begin{tabular}{|c|c|c|c|c|c|c|c|c|}
\hline \multirow[t]{2}{*}{ Item } & \multirow{2}{*}{\multicolumn{2}{|c|}{ Statement }} & \multicolumn{5}{|c|}{ Responses } & \multirow[t]{2}{*}{ Total } \\
\hline & & & 5 & 4 & 3 & 2 & 1 & \\
\hline \multirow[t]{2}{*}{7} & \multirow{2}{*}{$\begin{array}{l}\text { At the time of listening I found it difficult to } \\
\text { predict what would come next. }\end{array}$} & $\mathbf{F}$ & 61 & 27 & 6 & 5 & 19 & 118 \\
\hline & & $\%$ & 51.7 & 22.9 & 5.1 & 4.2 & 16.1 & 100 \\
\hline \multirow[t]{2}{*}{8} & \multirow{2}{*}{$\begin{array}{l}\text { I found it difficult to recognize the words I know } \\
\text { because of the way they are pronounced. }\end{array}$} & $\mathbf{F}$ & 27 & 51 & 16 & 19 & 5 & 118 \\
\hline & & $\%$ & 23 & 43.2 & 13.5 & 16.1 & 4.2 & 100 \\
\hline \multirow[t]{2}{*}{9} & \multirow{2}{*}{$\begin{array}{l}\text { I found it difficult to understand the meaning of } \\
\text { the spoken text without seeing the speaker's body } \\
\text { language (e.g. facial expressions of anger). }\end{array}$} & $\mathbf{F}$ & 26 & 53 & 12 & 13 & 14 & 118 \\
\hline & & $\%$ & 22 & 45 & 10.1 & 11 & 11.9 & 100 \\
\hline \multirow[t]{2}{*}{10} & \multirow{2}{*}{$\begin{array}{l}\text { I feel worried and discouraged when I don't } \\
\text { immediately understand the spoken text. }\end{array}$} & $\mathbf{F}$ & 20 & 40 & 28 & 14 & 16 & 118 \\
\hline & & $\%$ & 17 & 34 & 23.6 & 11.9 & 13.5 & 100 \\
\hline
\end{tabular}

Key: $\mathbf{5}=$ Always $\quad \mathbf{4}=$ Usually $\mathbf{3}=$ Sometimes $\quad \mathbf{2}=$ Rarely $\quad \mathbf{1}=$ Never $\quad \boldsymbol{F}=$ Frequency $\quad \boldsymbol{\%}=$ Percent

From the above results, we can conclude that almost all of the students in the study had difficulty in applying predictive skills and skills of getting general idea of a text. This has also its own implication on listening comprehension. There are evidences which show that employing listening strategies promote listening comprehension while inability to employ listening strategies affects listening comprehension. For example, Rost 
and Ross (1991) studied the relationship existed between listening strategies and listening comprehension; they found a positive correlation between them. This is also in line with Harmer's opinion (1991) which shows listeners' success at understanding the content of what they hear depends to a large extent on their expertise in the listening strategies.

From this result (see item number 8), it is possible to generalize that most students find it difficult to recognize the words they knew because of the way they are pronounced. This result is also consistent with Ur's declaration (1984), which states that if a word is pronounced differently from the way it was said when it was learnt, the listener may not recognize it as the same word, or may even miss its existence completely. At this point, this problem interferes with the learners listening comprehension.

From these results (see items number $9 \& 10$ ), we can understand that lack of non-verbal clues for what a speaker is saying can interfere with learners' listening comprehension although the problem may not be as serious as those listening problems presented earlier. Besides, there are words that most students normally recognize in their written form, but which the learners find difficult whenever they hear them in a stream of speech. When a student learns a new word or expression, it is believed the student usually learns both its written and spoken form.

\section{Table 5.1.3: Frequency and percentage of responses to items related to speaker factors.}

Speaker factors can be a source of listening comprehension problems. Problems of listening comprehension related to speaker can be seen in relation to natural speech, pronunciation, and varied accents.

\begin{tabular}{|c|c|c|c|c|c|c|c|c|}
\hline \multirow[t]{2}{*}{ Item } & \multirow{2}{*}{\multicolumn{2}{|c|}{ Statement }} & \multicolumn{5}{|c|}{ Responses } & \multirow[t]{2}{*}{ Total } \\
\hline & & & 5 & 4 & 3 & 2 & 1 & \\
\hline \multirow[t]{2}{*}{11} & \multirow{2}{*}{$\begin{array}{l}\text { Speaker's fast speech interfered with my listening } \\
\text { comprehension. }\end{array}$} & $\mathbf{F}$ & 55 & 20 & 10 & 15 & 18 & 118 \\
\hline & & $\%$ & 46.6 & 17 & 8.5 & 12.7 & 15.2 & 100 \\
\hline \multirow[t]{2}{*}{12} & \multirow{2}{*}{$\begin{array}{l}\text { Speaker's pronunciation interfered with my } \\
\text { listening comprehension. }\end{array}$} & $\mathbf{F}$ & 50 & 20 & 14 & 11 & 23 & 118 \\
\hline & & $\%$ & 42.4 & 17 & 11.8 & 9.3 & 19.5 & 100 \\
\hline
\end{tabular}

Key: $\mathbf{5}=$ Always $\quad \mathbf{4}=$ =Usually $\mathbf{3}=$ Sometimes $\quad \mathbf{2}$ =Rarely $\mathbf{1}=$ Never $\boldsymbol{F}=$ Frequency $\quad \boldsymbol{\%}=$ Percent

From the result acquired, therefore, we can understand that the natural speech of the native speakers (which the students perceive as fast speech, and different speaking styles) interfere with the listening comprehension of many of our students. In the Ethiopian context, the spoken features of English to which the students are accustomed to be to their teacher's speech with over clear expression. When such students who are accustomed to their teacher's accent, come across the pronunciation of the native speakers characterized by fast rate of delivery, unstructured language, incomplete sentences, false starts, and hesitations; it is difficult for them to understand the listening text (Underwood, 1989).

Table 5.1.4: Frequency and percentage of responses to items related to environmental factors.

The environmental factors can be one source of listening comprehension problems. In particular, unclear sounds resulting from poor-quality equipment and lack of sufficient time to accomplish tasks may influence students' listening performance.

\begin{tabular}{|c|c|c|c|c|c|c|c|c|}
\hline \multirow[t]{2}{*}{ Item } & \multirow{2}{*}{\multicolumn{2}{|c|}{ Statement }} & \multicolumn{5}{|c|}{ Responses } & \multirow[t]{2}{*}{ Total } \\
\hline & & & 5 & 4 & 3 & 2 & 1 & \\
\hline \multirow[t]{2}{*}{13} & \multirow{2}{*}{$\begin{array}{l}\text { Unclear sounds resulted from poor quality of tape } \\
\text { recorder or cassettes interfered with my listening } \\
\text { comprehension. }\end{array}$} & $\mathbf{F}$ & 28 & 60 & 6 & 5 & 19 & 118 \\
\hline & & $\%$ & 23.7 & 50.8 & 5.1 & 4.2 & 16.2 & 100 \\
\hline \multirow[t]{2}{*}{14} & \multirow{2}{*}{$\begin{array}{l}\text { Lack of sufficient time for carrying out the tasks } \\
\text { interfered with my listening performance. }\end{array}$} & $\mathbf{F}$ & 50 & 29 & 12 & 14 & 13 & 118 \\
\hline & & $\%$ & 42.4 & 24.6 & 10.1 & 11.9 & 11 & 100 \\
\hline
\end{tabular}

Kev: $\mathbf{5}=$ Always $\quad \mathbf{4}=$ Usually $\mathbf{3}=$ Sometimes $\quad \mathbf{2}=$ Rarely $\quad \mathbf{1}=$ Never $\quad \boldsymbol{F}=$ Frequency $\quad \boldsymbol{\%}=$ Percent

From the above data, we can deduce that poor-quality recording materials (see item number 13) interfere with the listening comprehension of too many students. This is in line with Yagang's statement (1994) which shows that the difficulty in listening comprehension is partly due to unclear sounds resulting from poor-quality equipment. Besides, (see item number 14) it is possible to say that lack of sufficient time for completing the tasks often interfere with the listening performance of too many learners.

Most of the interviewees (students) reported that they have deep-rooted difficulties of EFL listening for the reason that they didn't practice it at lower classes. Different students gave different reasons for this case; almost all said they didn't practice in their primary schools. And they had rural background and on lack of access to resources of the EFL listening. The learners had limited English vocabulary, poor knowledge of grammar, poor listening ability, etc.

The teachers emphasized on the teaching of listening strategies, such as, predictive skills, extracting specific information, getting the general picture, extracting detail information, recognizing functions and discourse patterns and deducting meaning from contexts. In addition, they were not restricted to one particular teaching method; they preferred to combine some teaching methods depending on the students' proficiency level and 
learning condition. They were strict to the students because they strongly believed that students should practice very hard and make good progress.

The teachers thought that the students were not that much motivated to learn EFL listening and they did not even know how to improve their listening comprehension. This may be due to the students' past experience and their poor listening ability.

\section{Conclusions}

The findings of the study shows that the learners' listening problems emerge from the defects of the listening materials, from the students lack of exposure to native speaker English, and from the inconvenience of the listening environment where the EFL listening takes place.. Especially the results of the analysis of the questionnaire and the interview indicate:

* Unfamiliar words, complex grammatical structures, long spoken text, complexity of sentences, unfamiliar topic, and a topic that cannot generate interest to listeners pose listening difficulties for EFL learners.

* The learners' inability to apply listening strategies, their inability to grasp pronunciation, inability to manage a bit challenging tasks, and the consequent frustration negatively affected the learners' listening comprehension.

* Unfamiliarity of the students with native speaker pronunciation (i.e. not especially carefully enunciated); overlap between speakers; and normal rate of delivery (which the learners perceived as fast speech) interfered with the learners listening comprehension.

\& Poor recordings and lack of sufficient time to carrying out tasks affected the learners' listening comprehension.

* The analysis of the students listening achievement scores as well as the teacher's and the students' responses indicate that most students' listening performance was low. The students' low scores could lead to the conclusion that the students have poor listening ability. This was partly responsible for the learners' poor listening comprehension.

\section{Recommendations}

The following recommendations are made based upon the findings of the study and the conclusions drawn.

* As far as the pronunciation is concerned, teachers should expose learners to recordings which provide students with practices of word level exercises (that deal with the practice of different sounds and sound combination which occur with single words) and sentence level exercises (that deal with the problems that emerge when words are put together to make sentence, e.g., assimilation or elision, contraction, distortion of sounds with in common collocation).

* With regard to fast speech, instructors should encourage students to listen to authentic texts of English so that they gain more chances to be acquainted with the real life EFL listening and to be familiar with the natural feature of the spoken English. The other way of tackling the above problems is through encouraging independent listening outside class. English songs, movies, videos, and the widely available radio programmes provide learners with opportunities to listen to English outside the classroom.

* As far as background knowledge is concerned, instructors should note its significant role in the interpretation of discourse. In the classroom, therefore, before asking students to listen, instructors should particularly take care about establishing common semantic fields between the listening topics and the listeners, especially when the topics demand cultural backgrounds that differ from that of the student. Instructors must ensure that students understand the context of the discourse before asking that they listen to a dialogue, joke, story, or any other spoken message.

* Since our purpose of teaching listening is to improve the learners listening skills, teachers should concentrate on aural comprehension itself, and it is best to base the task on exercises that demand predominantly listening and understanding (rather than reading, speaking and writing). For the success of these intentions, therefore, listening tasks should include exercises that require quick simple responses.

\section{References}

Badakhshan, S. (2008). The relationship between Emotional Intelligence and listening comprehension of Iranian intermediate EFL learners. Iranian Journal of Teaching Languages and Literatures, 9(10), 11-28.

Harmer, Jeremy. (1991). The Practice of English Language Teaching. Longman.

Hubbard, P. (Ed.). (2009). Computer Assisted Language Learning, Volume 3: Computer Mediated Communication for Language Learning. Critical Concepts in Linguistics Series. New York: Routledge.

Lindsay, C. and Knight, P. (2006). Learning and Teaching English. Oxford: OUP. 
Lund, R., J. (1991). A comparison of second language listening and reading comprehension. The modern language journal, p. 75

Muluken Abera. (2008). The Practice of Teaching Listening Skill. (Unpublished, MA Thesis). Addis Ababa: Addis Ababa University.

Nunan, D. (1998). Language Teaching Methodology, 268 pp. London: International Books Distributors Ltd.

Rost, M. (1994). Listening. London: Longman.

Rubin, J. (1994) A Review Of Second Language Listening Comprehension Research. The Modern Language Journal, 78 (2), 199-221.

Tesfaye Tilhun. (2008). Factors that Contribute to the Problems EFL Learners face in the Listening Skills Classroom. (Unpublished, MA Thesis). Addis Ababa: Addis Ababa University.

Tesfaye Tilahun, Melaku Zemedkun, Desalegn Amenu, and Tesfa Mezgebu. (2006). How Can Uniform Evaluating Criteria be Established in a Continuous Assessment of Sophomore English? An Action Research. Unpublished. BDU.

Steinberg S. (2007). An Introduction to Communication Studies. Juta and Company Ltd.

Underwood, M. (1989). Teaching listening. New York: Longman.

Ur, Penny. (1984). Teaching of English as a second or foreign language. Cambridge: CUP.

Yagang, F. (1994). Listening: Problems and solutions. In Thomas Kral (ed.) Teacher Development: Making the Right Moves. Washington, DC: English Language Programs Division, USIA. 